UDC 629-047.44.56

\title{
LENGTH OF LIFE CYCLE ASSESSMENT OF VEHICLE
}

\author{
O. M. Zagursky, E. A. Teslenko
}

National University of Life and Environmental Sciences of Ukraine, Ukraine.

Corresponding authors: zagurskiy_oleg@ukr.net.

Article history: Received: March 2019. Received in the revised form: April 2019. Accepted: May 2019. Bibl. 6, fig. 3, tabl. 0.

Abstract. In the article the theoretical analysis of methodical approaches to the definition of indicators of the life cycle of the motor transport industry and methods for assessing the status of rolling stock in the MTE (motor transport enterprise).

It is determined that in order to ensure a high level of volumetric indicators of the life cycle of the motor transport industry it is necessary to manage the life cycles of technologies, services and means of transport from the position of the complex object "Vehicle - transport service". The useful life of a vehicle is influenced by technological improvements, technological progress, reasonable projected economic changes, the movement of business centers, prohibited laws and other reasons. The criteria for establishing a reasonable replacement period for rolling stock of motor transport enterprises are environmentally friendly and safe vehicles.

The proposed method of estimating the life cycle of a vehicle on the basis of operational reliability allows for taking into account the majority of operational characteristics and contributes to the acceptance of optimal strategic decisions for the management of the MTE (motor transport enterprise). vehicle.

Key words: costs, life cycle, optimal lifetime,

\section{Introduction}

The activities of most domestic enterprises in the current economic conditions are characterized by an increase in the level of uncertainty of the environment associated with political instability, increased competition, the inability to achieve high results of economic activity by internal factors, etc. This is especially true for the MTE (motor transport enterprises), because in today's economic conditions advanced requirements are put forward for vehicles of their quality and safety of transportation. The exploitation of morally and physically outdated vehicles reduces the safety of transportation, adversely affects the environment, and, consequently, human health, leads to degreneration of the functioning of the transport system of the region, and so on. Therefore, updating the fleet of rolling stock is an important task facing both the motor transport industry and the economy of the country as a whole.

\section{Formulation of problem}

Currently, there are no problems with the a purchasing of rolling stock, the market is represented by cars in a wide range of manufacturers, models, load carrying capacity, in a state of new or used. Foreign cars at a relatively high starting price, compared with domestic or cheaper Russian analogues, have better consumer properties. However, with the arrival of foreign manufacturers, the problem of the diversity of rolling stock in the MTE (motor transport enterprise) is becoming increasingly relevant. The essence of the problem lies in the complexity of the organization of maintenance and repair of rolling stock, as it requires the use of different, expensive equipment suitable only for certain brands of cars and skilled workers.

\section{Analysis of recent research results}

Problems of management of transport enterprises were devoted to their work by Ukrainian scientists I. Aksonova, M. Bidnyak G. Bondarenko D. Vlasenko, A. Vorkut, T. Goncharenko, I. Kaminska, V. Shynkarenko, and a number of other scientists.

However, despite the sufficient number of works associated with the management of the MTE, the question of the influence of probabilistic processes on their work, at the moment, is not sufficiently studied. This disadvantage is partially eliminated by the use of the theory of mass service. But such a method initially involves the presence of queues in production, which negatively affects the economic performance of the MTE.

\section{Purpose of research}

The purpose of the work is to analyze methodological approaches to determining the indicators of the life cycle of the motor transport industry and methods for assessing the status of rolling stock MTE.

\section{Results of research}

The automotive industry occupies a special place in the country's economy and has a number of specific 
properties. To date, the evolutionary processes taking place in the automotive industry of the country are largely due to the transition to a market economy, which caused significant changes in the needs of consumers, changes in the structure and trends of the motor transport industry, changes in related industries and in the external environment of the country.

The most important factor influencing evolutionary processes in the motor transport industry is the demographic factor. After all, the higher the level of the population of the region, the more demanded services of transport enterprises, this is reflected not only in the increase in demand for passenger and freight transport, but also an increase in the number of vehicles that are in the personal use of the population, which in turn requires the creation of a suitable transport infrastructure service.

Over the past few decades, the demand for international passenger and freight connections in Ukraine has increased several times, so the process of integration into the world transport system is one of the priority tasks for the domestic transport industry. However, in order for Ukraine to be able to move closer to the level of transport systems of the developed countries, improvement of the transport sector of the country, in particular the development of motor transport enterprises (MTE), which is involved in freight transportation, is necessary to improve Ukraine's transport infrastructure, as a result of which there is a need to address the priority economic and management and environmental problems of the MTE; most of that requires a comprehensive approach. Our analysis made it possible to reveal the following problems of the MTE

1. The problem of management of motor transport enterprises.

2. An outdated fleet of vehicles.

3. The problem of compliance with environmental standards

4. Lack of proper system of utilization of spent spare parts vehicles

5. The problem of insufficient equipment of freight

6. Low quality and insufficient number of highways

7. The imperfection of insurance programs in the industry.

8. Lack of special lending programs in the field of freight transport.

Due to the solution of these problems, the part of freight traffic of the MTE in the total volume of cargo turnover will certainly increase significantly and possibly reach the European level, which, in turn, will ensure the formation within the country of interregional socioeconomic connectivity.

At the same time, the achievement of these goals requires management to develop an effective strategy for the development of MTE. Not so long ago, managers did not have the experience of developing a strategy as an integral part of enterprise management. Its application became necessary after the transition from the planned economy to the market. The lack of scientific development to help determine the goals of the activity has complicated the material and financial situation of enterprises even more.
The change in the economic situation in the country has had a negative effect on freight transport enterprises: freight volumes began to fall, rolling stock ageing, lack of new financial and revenue, personnel cuts, a decrease of the property base, and the reduction of enterprises. Also, a negative factor was the emergence of private carriers, which became serious competition for large freight motor transport enterprises, which caused a reduction in tariffs and other problems. Besides, permanent social, political and economic crises also did not contribute to the development of the automotive industry. Thus, during the 2013-2014 period, due to the economic crisis, the automotive sector suffered a fall in passenger (by 9.8\%) and cargo traffic (by 5.1\%) [2]. Under such circumstances it is important to objectively evaluate the company's capabilities, to determine the feasibility of further work in this field.

The motor transport industry is one of the most dynamically developed and changed, to date, the industries of the country's economy. In order to set the correct vector for the direction of its development and changes, it is necessary to take into account not only the current state of affairs in the industry, but also the previous and possible future (predicted) states. From this point of view, the motor transport system is of particular interest as an object of study of the theory of the life cycle of the industry itself and of a particular enterprise or vehicle in it.

It should be noted that the theory of the life cycle of the industry has not received such widespread as the theory of the life cycle of the organization, the product of the means of production. The most well-known is the analysis of the life cycle of the industry proposed by $\mathrm{M}$. Porter, which characterizes each stage of the life cycle of the industry in terms of competitive dynamics [1]. According to its work, each stage can be characterized by the following indicators:

- number and size of firms;

- the level of technological and strategic uncertainty;

- expenses;

- prices;

- characteristics of competitors and intensity of competition.

The inherent barriers to entry, exit and mobility are also an important characteristic of the industry's life cycle. The specificity of the transport industry, for which the main product is the provision of transport services, does not allow it to fully apply its existing life cycle models because it is not possible to link the life cycle of the industry with the life cycle of transport services, but it is possible to determine the relationship with transportation technologies.

Considering the technological basis of the automotive industry, it should be noted that, firstly: the technologies used in it are improved in terms of quality and safety of transportation, reduction of total costs and time for transportation, creation of the most convenient conditions for the consumer (delivery "from door to door"); and secondly: the process of clustering transport companies based on one of the most loaded or providing the largest range of services led to the emergence of 3PL and 4PL operators. Analyzing the historical development of society and motor transport, it is possible to distinguish 
several stages during which the discovery and changes that took place, set the vector of development of the motor transport industry and led to the introduction of certain transport technologies (Fig. 1).

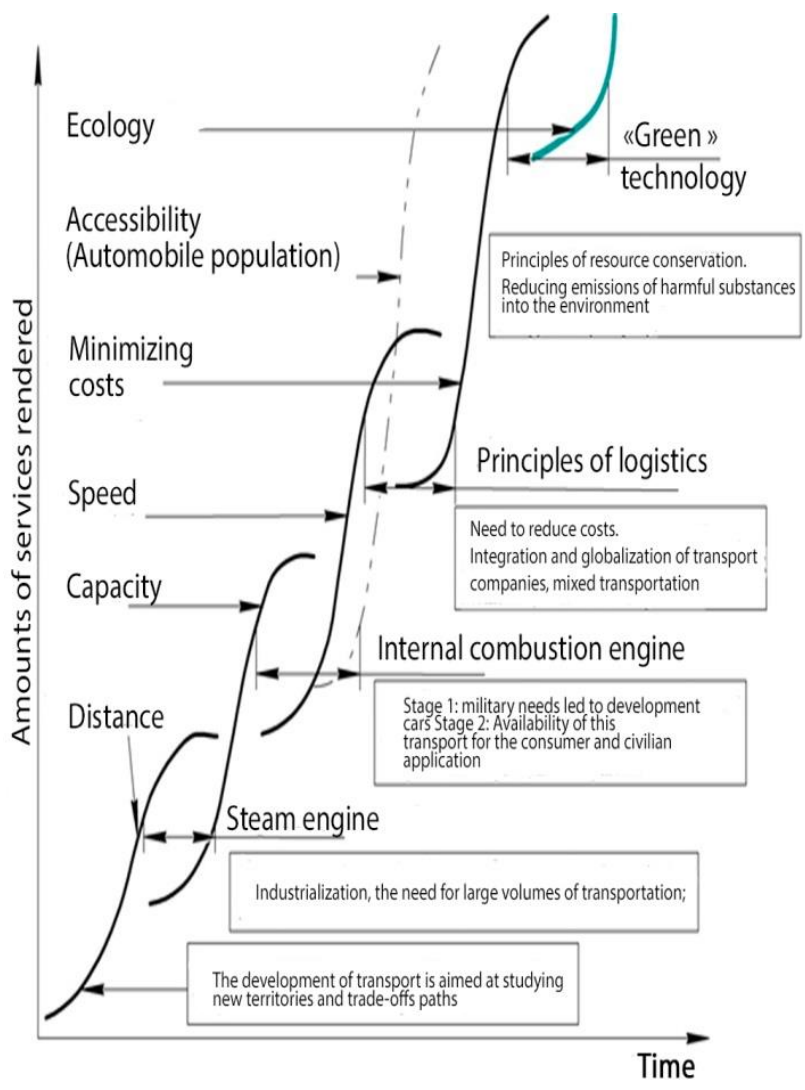

Fig. 1. Evolution of motor transport technologies.

The need to reduce costs and terms of transportation, providing convenience to the client in the struggle for leadership in the market of transport services, led to the development of logistics approaches in motor transport. In addition, companies appeared to be able to combine different types of transport to carry out transport work, combining the benefits of each of those involved, modes of transport. Today mixed transportation is developing in different directions: intermodal and multimodal, container and piggyback transportations.

The analysis of related industries and the views of the world community allows us to conclude that the next stage in the development of the transport industry will be the introduction of "green" technologies. As an example of the development of the European transport system, one can already see the reorientation of motor companies to use more environmentally friendly technologies. In order to increase competitiveness, domestic motor transport and logistics companies should also be guided by the world tendencies of "Sustainable Development", which ensure not only economic efficiency and quality of transportation, and do not harm the environment. Thus, according to studies «Towards Sustainable Logistics» [6] about $59 \%$ of companies surveyed believe that the use of "green" technologies for the transportation of their products will be a decisive factor in the choice of partners. And according to QSHE Global (survey of 5,400 respondents), we can conclude on the attitude towards the introduction of environmental technologies in the business processes of modern companies:

$-61 \%$ - cares about the environment;

- 67\% - choose partners oriented on "green" logistics;

- $82 \%$ - use the principles of "green" logistics to improve the image;

$-30 \%$ - are ready to pay extra for environmental technologies [5].

Consequently, considering the transport industry as a whole from the point of view of the theory of life cycle, it is difficult to speak of a collapse of the transport industry, since the task of moving cargoes and passengers will not lose its relevance. However, today it can be assumed that in the near future, within the framework of "green" logistics, there will be a shift away from hydrocarbon fuel to alternative sources of energy, in this case, road transport will radically change. Changes affect not only production but also exploitation, maintenance and infrastructure facilities. To ensure a high level of volumetric life cycle indicators motor transport industry it is necessary to manage the life cycles of technologies, services and means of transport from the position of the complex object " Vehicle - transport service". In addition to the vehicle itself, car makers sell a number of maintenance services, setting a certain mileage between the points of service and scheduled repairs. Compliance with maintenance schedules, timely replacement of technical fluids and consumable spare parts affects the efficiency of the vehicle, namely, fuel efficiency, safety and environmental friendliness.

Figure 2 shows the dependence of the efficiency of the vehicle, depending on the run.

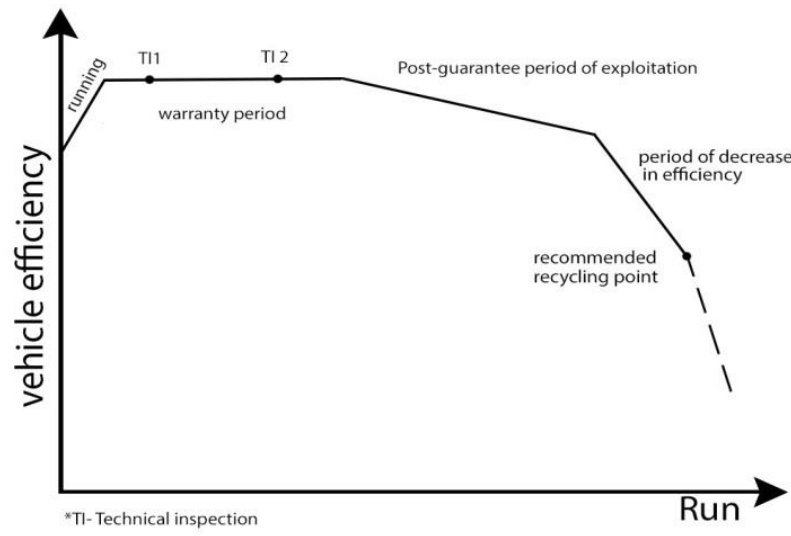

Fig. 2. Efficiency of the vehicle during the life cycle.

In the course of warranty maintenance, the operating procedure determines the periodicity of maintenance and diagnostics, replacement of operating materials and consumable parts. Thus, fulfillment of the requirements of the automobile manufacturer allows to maintain the maximum efficiency of the vehicle, and their noncompliance is the reason for the refusal of the warranty service. In the process of post-warranty service, the owner, as a rule, guided by general maintenance recommendations or applied as failure occurs. However, even if the recommendation is followed, at a certain run, the efficiency of the vehicle begins to decrease, which is 
associated with wear and tear and aging of knots, aggregates and car systems.

At the same time, it should be noted that car manufacturers go through the reduction of the life cycle of individual units and vehicles in general, in order to ensure a stable demand for products, and, on the other hand, reducing the life cycle of the car due to accelerated innovation, which require the introduction of mass production. To date, automakers say that they are developing and manufacturing cars, designed for a period of operation of 10 years. Therefore, it is logical to determine that after the end of these 10 years the car is subject to utilization, but a number of factors (market value of the vehicle, technological and production capacities of the vehicle utilization system, etc.) indicate that in practice this term will be longer.

The criteria for establishing a reasonable replacement period for rolling stock of motor transport enterprises are environmentally friendly and safe vehicles. However, vehicles older than 20 years are not restricted to the Euro standards, and therefore their exploitation is most harmful to the environment. It should be noted that from January 1, 2016, in Ukraine implemented a ban on the import and registration of new and old vehicles less than the standards of the Euro-5 environmental standard. And in 2018 in our country the ecological norms of Euro 6 should come into force. At least this is provided by the latest edition of the Law of Ukraine "On Certain Issues of Importation into the Customs Territory of Ukraine and Registration of Vehicles".

From the point of view of the safety of vehicles, additional studies are needed that will statistically allow the number of road traffic accidents resulting from technical malfunctions, mileage (service life) of vehicles to be linked and to determine the optimal term for which the vehicle should be deduced.

Thus, there is a need to legislatively limit the operation of vehicles beyond their effective (safe) work. Clause 14.1.138 of the Tax Code of Ukraine operates with the term "expected useful life (exploitation)". Legislation does not contain any algorithms or criteria for defining this term. The norms of item 145.1 of the Tax Code of Ukraine prescribe the minimum terms of use (for vehicles
- 5 years). That is, there are no legal restrictions on the use of vehicles in Ukraine, the use of vehicles whose technical condition and equipment meet the requirements of standards relating to road safety and environmental protection, as well as the rules of technical operation, manufacturers' instructions and other normative -technical documentation. In other words, if after the current or overhaul technical parameters of the transport unit meet the norms and standards, then such a vehicle can be used.

At the same time, the reliability of the logistics system of transportation is largely determined by the reliability of transport as its element. Transportation costs, including for the maintenance of a vehicle, account for more than $40 \%$ of the logistics costs. To shorten this article of expenses will allow the timely replacement of the vehicle, that is, the renewal of the fleet of rolling stock.

All equipment over time has the particularity to lose its value and to accumulate maintenance outgoings for proper condition. But it's always worth remembering the aging of rolling stock, in addition, the exploitation of outdated techniques leads to additional unpredictable costs during operation (breakdowns of the main units, which are already well worn out of service). All this leads to the impossibility of normal prediction of rolling stock, and significant financial losses.

With regard to determining the optimal lifetime of a vehicle, the most widely used method is that, as the criterion of optimality, a minimum cost per unit of output (output or work) is used. The essence of this method is as follows: with an increase in the life of the machine, the specific value of depreciation deductions falling on a unit of its development, decreases. The given method has disadvantages, among which the main thing is the unjustified choice of the minimum cost of the unit of work as a criterion of optimality. The term of use is determined, taking into account only material depreciation, and taken as the minimum allowable (tmin), replacement of the car before its completion requires capital investment and causes the increase in the cost of the unit of production [3, p. 414].

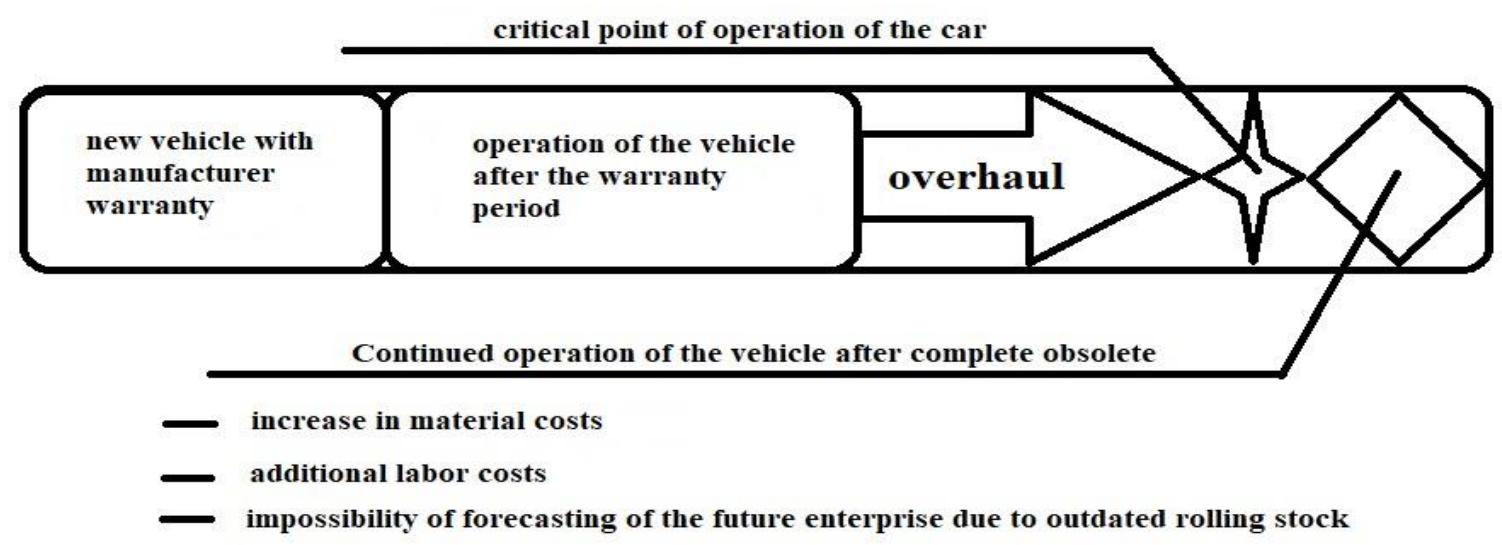

Fig. 3. Scheme of dependence of expenses on operation of vehicles and expenses for their updating outside the work area. 
If the company decides to upgrade its rolling stock, it is necessary to take into account the cost of acquiring a new truck on the $\mathrm{k}$ year of exploitation:

$$
p_{k}=\alpha+\beta(k-1)
$$

where $\alpha$ - the cost of a new truck is 2800 thousand UAH, $\beta$ - the amount at which the cost of a truck for each step increases 50 thousand UAH.

After $\mathrm{t}$ years of exploitation of the truck on the k-th year can be sold for

$$
\varphi(t)=p_{k} * 2^{-t}
$$

where $t$ is the year of exploitation.

All vehicles, loaders and any other technical and technological means, as soon as they receive the status of the sold, - immediately begin to lose their value in the presentation presented to other buyers. This can be said about their resource reserve. During the life of the product, the product is worn out and consumes more consumables and repairs.

The cost of maintaining a truck during the $\mathrm{k}$ year is

$$
r_{k}(t)=\gamma p_{k}(t+1)
$$

where $\gamma$ - coefficient of deductions for equipment maintenance, it includes expenses for fuel, engine oil and other consumables, as well as maintenance and repair, is 0,14 .

Final expenses at the end of the year are calculated by the formula:

$$
S_{t}=\varphi(t)+r_{k}(t)-p_{k}
$$

To the proceeds from the sale of the used truck add the cost of maintenance costs (costs are calculated at the beginning of the year, while the cost of service has not yet been paid, so these costs are considered as saved money and added to the balance) and subtract the cost of the new truck.

At the same time, it's worth remembering that the values of even one truck vary in different periods of time, but this method allows us to determine the approximate limits of depletion, which enables us to predict possible global breakdowns and react in a timely manner to them. That is, MTE management receives a modern tool for assessing the life cycle of a vehicle.

\section{Conclusions}

1. When using a vehicle, many things can be affected. They include the following:

- how often the machine is used;

- what was the age of the car at the time of purchase;

- how often it was repaired, updated or replaced;

- in which climate it was exploited.

2. Also, technological improvements, technical progress, reasonable projected economic changes, the movement of business centers, prohibited laws and other causes may also affect the useful life. All this needs to be taken into account before determining the expected useful life of the machine. The criteria for establishing a reasonable replacement period for rolling stock of motor transport enterprises are environmentally friendly and safe vehicles.

3. The proposed method of estimating the life cycle of a vehicle on the basis of operational reliability allows for taking into account the majority of operational characteristics and contributes to the acceptance of optimal strategic decisions for the management of MTE (motor transport enterprise).

\section{References}

1. Porter M. (2005). Competitive Strategy: Techniques for Analyzing Industries and Competitors. Moskva : Al'pina Biznes Buks.

2. Stratehichnyj plan rozvytku avtomobil'noho transportu ta dorozhn'oho hospodarstva na period do 2020 roku Nakaz Ministerstva infrastruktury Ukrainy 21 hrudnia 2015 roku № 548. URL: https://zakon.rada. gov.ua/rada/show/v0548733-15/sp:max20

3. Tkhoruk Ye. I., Kucher O. O. (2016). Vyznachennia optymal'noho terminu vykorystannia avtomobil'noho transportnoho zasobu iak parametra systemy onovlennia parku rukhomoho skladu, Mizhvuzivs'kyj zbirnyk "NAUKOVI NOTATKY". Luts'k, Vol. 55, 412-417.

4. Alexandrova, $K$. (2014). The links of one Chain, The RZD Partner International, Vol. 3 (39). 38-39.

5. Chandler A. D. Jr. (1962). Strategy and Structure: Chaptersin the History of American Enterprise, MIT Press : Cambridge, MA.

6. Christof Dr., Ehrhart E. Delivering Tomorrow: Towards Sustainable Logistics" URL: http://www.delivering-tomorrow.com free.

\section{Список літератури}

1. Портер M. Конкурентная стратегия : методика анализа отраслей и конкурентов; пер. с англ. Москва. Альпина Бизнес Букс, 2005. 454 с.

2. Стратегічний план розвитку автомобільного транспорту та дорожнього господарства на період до 2020 року Наказ Міністерства інфраструктури України 21 грудня 2015 року № 548. URL: https://zakon.rada. gov.ua/rada/show/v054873315/sp:max 20.

3. Тхорук $Є$. I., Кучер О. О. Визначення оптимального терміну використання автомобільного транспортного засобу як параметра системи оновлення парку рухомого складу. Міжвузівський збірник "Наукові Нотатки". Луцьк, 2016. Вип. № 55. C. 412-417.

4. Alexandrova, $K$. The links of one Chain. The RZD Partner International, 2014. № 3 (39). C. 38-39.

5. Chandler A. D. Jr. Strategy and Structure: Chaptersin the History of American Enterprise. MIT Press : Cambridge, MA, 1962. 345 p.

6. Christof Dr., Ehrhart E. Delivering Tomorrow: Towards Sustainable Logistics. Mode of access: http:// www.delivering-tomorrow.com.

\section{ОЦІНКА ТРИВАЛОСТІ ЖИТТЕВОГО ЦИКЛУ ТРАНСПОРТНОГО ЗАСОБУ О. М. Загурський, С. А. Тесленко}


Анотація. В статті проведено теоретичний аналіз методичних підходів до визначення показників життєвого циклу автотранспортної галузі та методів оцінки стану рухомого складу АТП.

Визначено, що для забезпечення високого рівня об'ємних показників життєвого циклу автотранспортної галузі необхідно управляти життєвими циклами технологій, послуг і засобів перевезень 3 позиції комплексного об'єкта «Транспортний засіб - транспортний сервіс». На тривалість корисного життя транспортного засобу впливають технологічні поліпшення, технічний прогрес, розумні прогнозовані економічні зміни, переміщення ділових центрів, заборонні закони й інші причини. Критеріями для встановлення обгрунтованого терміну заміни рухомого складу автотранспортних підприємств $\epsilon$ екологічність i безпека транспортних засобів.

Запропонована методика оцінки тривалості життєвого циклу транспортного засобу на основі експлуатаційної надійності дозволяє врахувати більшість експлуатаційних характеристик та сприяє прийняттю оптимальних стратегічних рішень 3 управління АТП.

Ключові слова: витрати, життєвий цикл, оптимальний строк експлуатації, транспортний засіб.

\section{ОЦЕНКА ПРОДОЛЖИТЕЛЬНОСТИ ЖИЗНЕННОГО ЦИКЛА ТРАНСПОРТНОГО СРЕДСТВА О. Н. Загурский, Е. А. Тесленко}

Аннотация. В статье проведен теоретический анализ методических подходов к определению показателей жизненного цикла автотранспортной отрасли и методов оценки состояния подвижного состава АТП.

Определено, что для обеспечения высокого уровня объемных показателей жизненного цикла автотранспортной отрасли необходимо управлять жизненными циклами технологий, услуг и средств перевозок с позиции комплексного объекта «Транспортное средство - транспортный сервис». На продолжительность полезной жизни транспортного средства влияют технологические улучшения, технический прогресс, умные прогнозируемые экономические изменения, перемещения деловых центров, запрещающие законы и другие причины. Критериями для установления обоснованного срока замены подвижного состава автотранспортных предприятий является экологичность и безопасность транспортных средств.

Предложенная методика оценки продолжительности жизненного цикла транспортного средства на основе эксплуатационной надежности позволяет учесть большинство эксплуатационных характеристик и способствует принятию оптимальных стратегических решений по управлению АТП.

Ключевые слова: затраты, жизненный цикл, оптимальный срок эксплуатации, транспортное средство.
O. М. Загурський ORCID 0000-0002-5407-8466.

С. А. Тесленко ORCID 0000-0003-3811-6183. 